\title{
PENGARUH AGGRESIVITAS PAJAK, KEPEMILIKAN KELUARGA \\ DAN UKURAN PERUSAHAAN TERHADAP KEBIJAKAN HUTANG \\ PADA PERUSAHAAN MANUFAKTUR TAHUN 2012-2014
}

\author{
Ernie Riswandari \\ Universitas Bunda Mulia \\ eriswandari@bundamulia.ac.id
}

\begin{abstract}
This study examined the policy of the variables affecting debt is aggresivitas tax enterprises.At the family ownership and the size of the manufacturing companies listed in Indonesia Stock Exchange in 2012-2014 .

This research is a quantitative study using regression test is intended to test the effect of independent variables on the dependent variable.

Based on these data and if the data that has been done shows that the family ownership has a positive and significant impact on the debt policy. While aggresivitas tax and company size affect positively but not significant.
\end{abstract}

Key Word : debt policy, family ownership, tax aggressiveness, the size of the company

\section{Pendahuluan}

Aset yang dimiliki sebuah perusahaan dan digunakan untuk menunjang kegiatan operasional perusahaan dapat diperoleh dari dana yang bersumber dengan menerbitkan saham maupun dengan cara berhutang. Komposisi hutang dan modal yang dimiliki perusahaan dikenal dengan nama struktur modal. Dalam pemilihan struktur modal perusahaan pilihan utang dan modal sebagai sumber pendanaan perusahaan merupakan pilihan yang penting. Struktur modal yang optimal akan mempertimbangkan keuntungan dari pengurangan pajak. Pendanaan perusahaan dengan menggunakan hutang akan menyebabkan timbulnya beban hutang (Cost of Debt), dimana beban yang muncul dari adanya pendanaan hutang tersebut merupakan beban yang dapat dikurangkan dalam menghitung penghasilan kena pajak (deductible expenses), sedangkan penggunaan sumber dana dengan menerbitkan saham akan muncul 
biaya modal yang berupa deviden. Pemilihan pada struktur modal akan mempengaruhi perilaku perusahaan dalam menentukan kebijakan hutang. Pemerintah selalu berusaha untuk dapat memungut pajak yang sebanyak-banyaknya dari rakyat guna meningkatkan pendapatan negara, sedangkan bagi perusahaan pajak merupakan beban yang akan mengurangi perolehan laba setelah pajak. Terlihat bahwa terdapat dua pandangan yang berbeda terhadap pajak sehingga beberapa perusahaan banyak yang melakukan perencanaan pajak yang merupakan proses mengorganisasi usaha wajib pajak orang pribadi maupun badan usaha sedemikian rupa dengan memanfaatkan berbagai celah kemungkinan yang dapat ditempuh perusahaan dalam koridor ketentuan peraturan perpajakan agar perusahaan dapat membayar pajak dalam jumlah minimum.Modus yang biasanya digunakan untuk menghindari pajak salah satunya adalah tax avoidance (penghindaran pajak), adalah upaya penghindaran pajak yang dilakukan secara legal dan aman bagi wajib pajak karena tidak bertentangan dengan ketentuan perpajakan. Semakin aggressive perencanaan pajak yang dilakukan dalam rangka untuk meminimumkan beban pajak dikenal sebagai agresivitas pajak.

Perusahaan yang sahamnya dijual di pasar modal artinya bahwa perusahaan tersebut sahamnya dapat dimiliki oleh masyarakat, namun ada juga sebagian saham yang diterbitkan oleh perusahaan tersebut dimiliki oleh keluarga pendiri perusahaan tersebut, dengan tetap menjaga prosentase saham kepemilikan keluarga, mereka masih tetap dapat mengendalikan usahanya oleh karena itu hal tersebut dapat mempengaruhi perusahaan dalam hal pengambilan kebijakan dalam menetukan sumber pendanaan yang akan dipilih.

Dengan berdasarkan pada uraian di atas peneliti ingin menguji apakah aggresivitas pajak, kepemilikan keluarga dan ukuran perusahaan akan mempengaruhi kebijakan hutang. Sehingga dapat disusun rumusan masalah sebagai berikut:

a. Apakah terdapat pengaruh positif dan signifikan aggresivitas pajakterhadap 
kebijakan hutang pada perusahaan manufaktur tahun 2012-2014?

b. Apakah terdapat pengaruh positif dan signifikan kepemilikan keluargaterhadap kebijakan hutang pada perusahaan manufaktur tahun 2012-2014?

c. Apakah terdapat pengaruh positif dan signifikan ukuran perusahaanterhadap kebijakan hutang pada perusahaan manufaktur tahun 2012-2014?

\section{Tinjauan Pustaka}

\subsection{Kerangka Teori}

\subsubsection{Teori Pecking Order}

Menurut Halomoan et.al (2004) dalam Indahningrum et.al (2009) struktur pendanaan suatu perusahaan mengikuti hirarki dimulai dari sumber dana termurah, dana internal hingga saham sebagai sumber terakhir jika struktur modal dalam perusahaan dapat mempengaruhi biaya modalnya maka manajemen struktur modal merupakan hal yang penting dalam manajemen keuangan. Menurut Sander dan Myer (1992) dalam Indahningrum (2009). Dalam bentuk yang paling sederhana
Pecking Order Model dalam pendanaan perusahaan menjelaskan bahwa ketika arus kas internal perusahaan tidak cukup mendanai investasi real dan deviden, perusahaan akan menerbitkan hutang. Saham tidak akan pernah diterbitkan kecuali biaya financial distressperusahaan tinggi dan perusahaan hanya menerbitkan junk debt.

\subsubsection{Agency Theori}

Agency theory merupakan hubungan keagenan antara principal dengan agen. Dalam konteks perusahaan, masalah keagenan yang dihadapi investor mengacu pada kesulitan investor untuk memastikan bahwa dananya tidak disalahgunakan oleh manajemen perusahaan untuk mendanai kegiatan yang tidak menguntungkan. Hubungan keagenan dapat menyebabkan konflik pada saat pihak-pihak yang bersangkutan memiliki kepentingan yang berbeda Menurut Jensen dan Meckling (1976) dalam Wiranata dan Nugrahanti (2013), penyebab konflik antara manajer dan pemegang saham diantaranya adalah pembuatan keputusan yang berkaitan 
dengan aktivitas pencarian dana dan bagaimana dana yang diperoleh tersebut diinvestasikan.

\subsubsection{Kebijakan Hutang}

Hutang merupakan kewajiban yang timbul akibat peristiwa yang terjadi di masa lampau yang menyebabkan timbulnya kewajiban yang harus dipenuhi dengan mengorbankan asset yang dimilikinya. Dalam mencukupi modal kerja perusahaan, dapat dilakukan dengan mencari pinjaman dari pihak eksternal perusahaan. Dalam hal ini biasanya perusahaan mengajukan pinjaman pada bank atau menerbitkan surat hutang.

Salah satu sebab timbulnya konflik keagenan antara manajer dan pemegang saham yang disebabkan oleh keputusan pendanaan. Keputusan pendanaan secara sederhana dapat diartikan sebagai keputusan manajemen dalam menentukan sumber-sumber pendanaan dari modal internal yaitu modal ditahan atau dari modal eksternal, modal sendiri, dan atau melalui hutang (Waluyo, 2002 dalam Indahningrum et.al, 2009).
Menurut Murni, 2002 dan Andriana dalam Indahningrum et.al, 2009 untuk memenuhi kebutuhan pendanaan pemegang saham lebih menginginkan pendanaan perusahaan dibiayai dengan hutang karena dengan pendanaan hutang, hak mereka terhadap perusahaan tidak akan berkurang. Tetapi manajer tidak menyukai pendanaan dengan alasan bahwa hutang mengandung resiko yang tinggi. Manajemen perusahaan cenderung lebih menginginkan memperoleh keuntungan sebesarbesarnya dengan pihak lain. Perilaku ini disebut dengan perilaku keterbatasan rasional (baounded rationality).

\subsubsection{Aggresivitas Pajak}

Agressivitas pajak sebagai kegiatan perencanaan pajak semua perusahaan yang terlibat dalam usaha mengurangi tingkat pajak yang efektif. Perusahaan yang agresif terhadap pajak ditandai dengan transparansi yang lebih rendah. (Lanis dan Richardson, 2012)

Menurut Frank et al (2009) dalam Fikriyah tindakan pajak agresif adalah suatu tindakan yang ditujukan 
untuk menurunkan laba kena pajak melalui perencanaan pajak baik menggunakan cara yang tergolong atau tidak tergolong tax evasion.

Cara untuk mengukur perusahaan yang melakukan agresivitas pajak yaitu dengan menggunakan proksi Effective Tax Rates (ETR). Menurut Lanis dan Richardson (2012) dalam Natasya (2014) menyatakan bahwa ETR merupakan proksi yang paling banyak digunakan pada penelitian terdahulu. Proksi ETR dinilai menjadi indicator adanya agresivitas pajak apabila memiliki ETR yang mendekati nol. Semakin rendah nilai ETR yang dimiliki perusahaan maka semakin tinggi tingkat agresivitas pajak. ETR yang rendah menunjukan beban pajak penghasilan lebih kecil dari pendapatan sebelum pajak.

\subsubsection{Kepemilikan Keluarga}

Menurut Porta, et al. (1998) dalam

Rebecca dan Siregar (2013) kepemilikan keluarga didefinisikan sebagai kepemilikan dari individu dan kepemilikan dari perusahaan tertutup (di atas 5\%), yang bukan perusahaan publik, negara, ataupu institusi keuangan. Pengukuran sensitivitas kepemilikan keluarga mengacu pada PSAK 15 (revisi 2009) yang menyatakan jika investor memiliki secara langsung maupun tidak langsung, 20\% atau lebih hak suara investee, maka investor dianggap mempunyai pengaruh signifikan. Menurut Sari (2010) dalam penelitiannya mengklasifikasikan kepemilikan keluarga dalam variabel dummy yaitu satu untuk kepemilikan keluarga tinggi $(>50 \%)$ dan 0 untuk kepemilikan keluarga rendah $(<50 \%)$.

\subsubsection{Ukuran Perusahaan}

Perusahaan yang besar cenderung untuk selalu menjaga nama baiknya atau image di mata masyarakat. SIZE atau ukuran perusahaan adalah ukuranyang menunjukkan besar kecilnya suatu perusahaan,yang dapat dilihat dari nilai pasar saham, kapitalisasipasar, total aset, dan lainlain (Widjadja, 2009 dalam Junila, 2014). Dalam penelitian ini ukuran perusahaan dilihat dari total asset perusahaan Aset adalah sumberdaya yang dikuasai oleh perusahaan sebagai akibatdari peristiwa masa lalu dan manfaat ekonomi masadepan yang diharapkan akan diperoleh perusahaan.Aset perusahaan dibeli dan dikelola oleh 
perusahaanuntuk memperoleh pendapatan yang maksimal..

Semakin besar total asset semakin besar ukuran perusahaan.

\subsection{Pengembangan Hipotesis}

\subsubsection{Pengaruh Aggresivitas Pajak}

\section{Terhadap Kebijakan Hutang}

Keputusan untuk memilih sumber pendanaan melalui hutang dari kebijakan yang diambil akan menimbulkan adanya beban bunga yang harus dibayar perusahaan dan diketahui bahwa beban bunga dalam perpajakan dapat dipergunakan sebagai pengurang yang nantinya akan menyebabkan penghasilan kena pajaknya menjadi turun dan pastinya akan berdampak pada turunnya jumlah pajak yang harus dibayarkan. Perusahaan cenderung untuk mencari celah yang dapat dilakukan agar dapat menurunkan pajak terhutangnya melalui kegiataan perencanaan pajak atau melakukan aggresivitas pajak

Berdasarkan pada paparan tersebut dapat disusun hipotesa sebagai berikut ;

Ha1: Terdapat pengaruh positif dan signifikan aggresivitas pajak terhadap kebijakan hutang pada perusahaan manufaktur tahun 20122014

\subsubsection{Pengaruh Kepemilikan} Keluarga Terhadap Kebijakan

\section{Hutang}

Kebijakan pemilihan sumber pendaan melalui hutang akan menimbulkan kewajiban perusahaan harus membayar bunga. Sedangkan bila memilih sumber pendaan melalui penerbitan saham akan mempengaruhi kepemilikan terhadap perusahaan tersebut. Sehingga sebuah perusahaan yang dimiliki oleh keluarga cenderung lebih memilih kebijakan hutang dalam memenuhi kebutuhan dananya karena kebijakan tersebut tidak akan mempengaruhi kepemilikannya terhadap perusahaan tersebut.

Berdasarkan pada paparan tersebut dapat disusun hipotesa sebagai berikut ;

Ha2 : Terdapat pengaruh positif dan signifikan kepemilikan keluarga terhadap kebijakan hutang pada perusahaan manufaktur tahun 20122014

2.2.3 Pengaruh Ukuran Perusahaan Terhadap Kebijakan Hutang 
Kebutuhan akan modal yang diperlukan untuk perusahaan besar biasanya lebih besar bila dibandingkan dengan perusahaan kecil, demikian juga dengan kebijakan hutang dalam memenuhi sumber pendanaannya lebih tinggi.

Berdasarkan pada paparan tersebut dapat disusun hipotesa sebagai berikut ;

Ha3 : Terdapat pengaruh positif dan signifikan ukuran perusahaan terhadap kebijakan hutang pada perusahaan manufaktur tahun 20122014

\section{Metodologi Penelitian}

Penelitian ini menurut jenis data yang dipergunakan merupakan penelitian kuantitatif sedangkan menurut tingkat eksplanasinya merupakan penelitian yang bertujuan untuk mengetahui pengaruh antar dua variable atau lebih yaitu untuk menguji pengaruh aggresivitas pajak, kepemilikan keluarga dan ukuran perusahaan terhadap kebijakan hutang.
Populasi dalam penelitian ini adalah seluruh perusahaan manufaktur yang terdaftar di Bursa Efek Indonesia pada tahun 2012-2014.

Sampel adalah suatu prosedur pengambilan data di mana hanya sebagian populasi yang diambil dan dipergunakan untuk menentukan sifat serta jumlah yang dikehendaki dari suatu populasi. Teknik pengambilan sampel yang dipergunakan adalah purposive samplingyaitu (Sofian Siregar, 2013). Sampel yang dipergunakan dalam penelitian ini adalah sebanyak 22 perusahaan.

Data yang digunakan merupakan data kuantitaif. Sedangkan sumber data yang digunakan merupakan jenis data sekunder. Penelitian ini menggunakan data sekunder yang diperoleh dari laporan keuangan tahunan perusahaan manufaktur yang listing di BEI selama tahun 2012 dan tahun 2014, yang didokumentasikan dalam www.idx.co.id

Variabel yang digunakan dalam penelitian ini adalah ; 
Tabel 1.1

Definisi Variabel

\begin{tabular}{|c|c|c|}
\hline No. & Variabel & Proxy \\
\hline 1 & $\begin{array}{l}\text { Aggresivitas Pajak } \\
\text { (Variabel Independent) }\end{array}$ & $\begin{array}{l}\text { Effective Tax rates (ETR) = Beban Pajak } \\
\text { /Pendapatan Sebelum Pajak }\end{array}$ \\
\hline 2 & $\begin{array}{l}\text { Kepemilikan Keluarga } \\
\text { (Variabel Independent) }\end{array}$ & $\begin{array}{l}\text { kepemilikan keluarga dalam variabel dummy } \\
\text { yaitu satu untuk kepemilikan keluarga tinggi } \\
(>50 \%) \text { dan } 0 \text { untuk kepemilikan keluarga } \\
\text { rendah }(<50 \%) \text {. }\end{array}$ \\
\hline 3 & $\begin{array}{l}\text { Ukuran Perusahaan } \\
\text { (Variabel Independent) }\end{array}$ & $S I Z E=\operatorname{Ln}($ Asset $)$ \\
\hline 4 & $\begin{array}{l}\text { Kebijakan Hutang } \\
\text { (Variabel Dependent) }\end{array}$ & $\begin{array}{l}\text { Debt Equity Ratio }(\text { DER })=\text { Hutang Jangka } \\
\text { Panjang/Total Ekuitas }\end{array}$ \\
\hline
\end{tabular}

Pengujian hipotesis penelitian dalam hal ini dilakukan dengan menggunakan persamaan statistik, yaitu dengan menggunakan analisis regresi multivariat. Adapun alat analisis yang digunakan adalah;

- Uji Statistik t

Untuk menguji seberapa jauh pengaruh satu variable independent secara individual dalam menerangkan variasi variable dependent.

- Uji Statistik F

Untuk menguji apakah semua variable bebas yang dimasukkan dalam model mempunyai pengaruh secara bersama-sama terhadap variable dependen.

- Koefisien Determinasi
Untuk mengukur seberapa jauh kemampuan model dalam menerangkan variasi variable dependen.

- Interpretasi hasil

Dari hasil analisis yang telah dilakukan, akan diinterpretasikan bagaimana hasil yang diperoleh disesuaikan dengan teori dan penelitian-penelitian yang telah dilakukan dan yang terakhir melakukan penarikan kesimpulan.

\section{Hasil Penelitian dan}

\section{Pembahasan}

Data yang digunakan dalam penelitian ini adalah data sekunder yang bersumber dari laporan keuangan perusahaan manufaktur tahun 2012-2014. Dengan 
berdasarkan proxy yang regresi. Berdasarkan hasil olah data dipergunakan untuk mewakili yang telah dilakukan untuk menguji variable yang diteliti dan telah lulus dari uji asumsi klasik sehingga telah hipotesis diperoleh hasil sebagai berikut memenuhi syarat untuk dilakukan uji

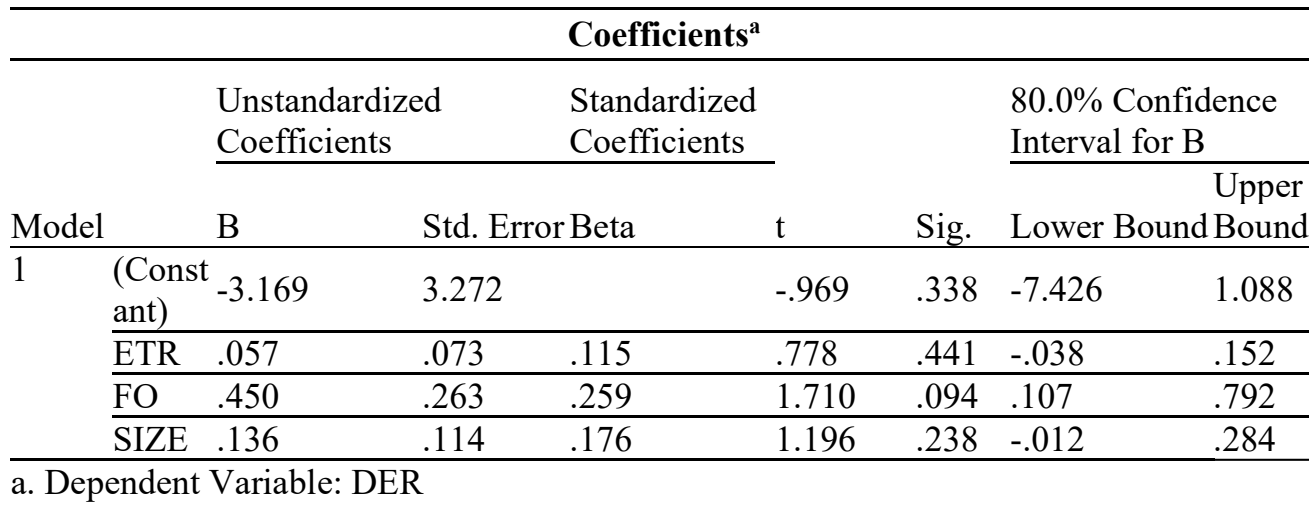

Aggresivitas pajak yang diproxikan dengan Effective Tax ratio (ETR)berpengaruh secara positif namun tidak signifikan karena lebih besar dari 0,05 sehingga hipotesis pertama ditolak yang artinya bahwa kebijakan hutang yang dilakukan perusahaan bukanlah disebabkan karena adanya aggresivitas pajak dimana perusahaan melakukan kebijakan tersebut bukanlah semata dikarenakan beban bunga yang timbul dari hutang dapat digunakan sebagai pengurang penghasilan kena pajak yang nantinya akan meyebabkan besarnya pajak terhutang menjadi turun.
Kepemilikan keluarga yang merupakan variable dummy dimana 1 untuk kepemilikan keluarga tinggi $(>50 \%)$ dan 0 untuk kepemilikan keluarga rendah $(<50 \%)$, dari hasil uji regresi yang telah dilakukan terdapat pengaruh positif dan signifikan dengan tingkat signifikansi lebih kecil dari 0,05 yang artinya bahwa hipotesis ke dua yang menyatakan bahwa terdapat pengaruh positif dan signifikan kepemilikan keluarga terhadap kebijakan hutang. Semakin tinggi kepemilikan keluarga (Family Ownership) kebijakan pemilihan sumber pendanaan melalui kebijakan hutang yang dilakukan semakin tinggi karena dengan kebijakan hutang yang dilakukan tidak akan menganggu 
kepemilikannya terhadap perusahaan tersebut sehingga perusahaan tersebut masih dapat dikendalikan oleh keluaraga tersebut.

Ukuran perusahaan berpengaruh positif namun tidak signifikan terhadap kebijakan hutang karena hasil olah data yang telah dilakukan bahwa tingkat signifikansinya lebih besar dari 0,05 dengan demikian hipotesis ke tiga ditolakyang artinya bahwa ukuran perusahaan bukanlah sebagai factor yang menentukan kebijakan hutang yangdigunakan untuk memenuhi kebutuhan pendanaan perusahaan, karena perusahaan yang besar yang struktur kepemilikan sahamnya tidak terpusat apabila perusahaan tersebut membutuhkan dana perusahaan tersebut lebih suka sumber pendanaanya diaperoleh dengan cara menerbitkan saham bukan melalui hutang karena pendanaan melalui hutang akan mendatangkan resiko yang tinggi untuk perusahaan karena perusahaan harus membayar hutang meskipun kondisi perusahaan sedang keadaan merugi perusahaan harus tetap membayar hutang hal tersebut akan mengganggu likuiditas perusahaan.

\section{Simpulan}

Dari penelitian ini dapat disimpulkan bahwa kebijakan hutang yang dilakukan perusahaan disebabkan oleh variabel kepemilikan keluarga. Sedangkan aggresivitas pajak dan ukuran perusahaan berpengaruh secara positif namun tidak signifikan yang artinya kedua variable tersebut pengaruhnya tidaklah terlalu berarti. Dalam pemilihan sumber pendanaan perusahaan melalui hutang, prosentase kepemilikan perusahaan terhadap perusahaan tersebut tidaklah akan terganggu dengan demikian pemegang saham keluarga pendiri masih dapat tetap mengendalikan perusahaan tersebut dengan aman.

Bagi peneliti berikutnya yang tertarik untuk meneliti tentang kebijakan hutang dapat dilakukan penambahan terhadap variable yang diteliti karena banyak factor yang mendorong perusahaan melakukan pemenuhan pendanaan perusahaan melalui hutang. 


\section{Daftar Pustaka}

Bhojraj, S., \& Sengupta, P. (2003). Effect of corporate governance on bond ratings and yields: The role of institutional investors and outside directors. Journal of Business 76, 455-47.

Chairil Anwar (2015), Manajemen Perpajakan, Gramedia, Jakarta

Frank, M., Lynch, L., \& Rego, S. (2009). Tax reporting aggressiveness and its relation to aggressive financial reporting. The Accounting Review, 84, 467496.

Graham, J.R., \& Tucker, A. (2006).Tax shelters and corporate debt policy.Journal of Financial Economics 81, 563-594.

Joni,Lina, (2010), Faktor-Faktor yang Mempengaruhi Struktur Modal, Jurnal Bisnis dan Akuntansi Vol.12 No.2,81-96.

Junilla Hadi, Yenni Mangoting,(2014), Pengaruh Struktur Kepemilikan dan Karateristik Dewan Terhadap Agresivitas Pajak, Tax and Accounting Review, Vol. 4 N0.2

Lanis, Richardson(2012), Corporate social responsibility and tax aggressiveness : a test of legitimacy theory, Journal of Applied AccountingResearch

\begin{tabular}{|c|c|}
\hline Indahnigrum & (2009) \\
\hline Kepemilika & \\
\hline Kepemilika & \\
\hline
\end{tabular}

Deviden, Pertumbuhan Perusahaan, Free Cash Flow dan Profitabilitas Terhadap Kebijakan Hutang Perusahaan, Jurnal Bisnis Akuntansi, Vol.11 No.3

Priyatno (2011), SPSS Analisis Statistik Data, Edisi 1,Media Kom, Yogyakarta

Pittman, J., Fortin, S., (2004).Auditor choice and the cost of debt capital for newly public firms.Journal of Accounting and Economics 37, 113-136.

Rebecca, Yulisa dan Sylvia Veronica Siregar. 2012. Pengaruh Corporate Governance Index, Kepemilikan Keluarga, dan Kepemilikan Institusional terhadap Biaya Ekuitas dan Biaya Utang: Studi Empiri pada Perusahaan Manufaktur yang Terdaftar di BEI. Simposium Nasional Akuntansi XV Banjarmasin.

Riyanto, Bambang (2001), Manajemen Keuangan, BPFE, Yogyakarta

Sari, D.K. (2010).Ownership Characteristics, Corporate Governance, and Tax Aggressiveness. The 3rd Accounting and The $2^{\text {nd }}$ Dotoral Colloquium, Bridging the Gap between Theory, Research and Practice : IFRS Convergence and Application Faculty of Economics Universitas IndonesiaBaliIndonesia, 27 - 28 Oktober 2010.

Widyaningdyah, Agnes Utari, (2001) Analisis Faktor-Faktor yang Berpengaruh Tehadap Eraning 
Manajemen pada Perusahaan Go Publik di Indonesia, Jurnal Akuntansi dan Keuangan Vol. 3 No.2.

Wiranata (2013) Pengaruh Struktur Kepemilikan Terhadap Profitabilitas Perusahaan Manufaktur di Indonesia, Jurnal Akuntansi Keuangan Vol.15 No.1 